\title{
Functional characterization of two enhancers located downstream FOXP2
}

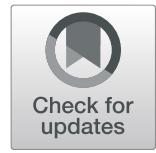

\author{
Raúl Torres-Ruiz ${ }^{1}$, Antonio Benítez-Burraco ${ }^{2^{*}}$ (D), Marta Martínez-Lage ${ }^{1}$, Sandra Rodríguez-Perales ${ }^{1 \dagger}$ \\ and Paloma García-Bellido $3,4+$
}

\begin{abstract}
Background: Mutations in the coding region of FOXP2 are known to cause speech and language impairment. However, it is not clear how dysregulation of the gene contributes to language deficit. Interestingly, microdeletions of the region downstream the gene have been associated with cognitive deficits.

Methods: Here, we investigate changes in FOXP2 expression in the SK-N-MC neuroblastoma human cell line after deletion by CRISPR-Cas9 of two enhancers located downstream of the gene.

Results: Deletion of any of these two functional enhancers downregulates FOXP2, but also upregulates the closest $3^{\prime}$ gene MDFIC. Because this effect is not statistically significant in a HEK 293 cell line, derived from the human kidney, both enhancers might confer a tissue specific regulation to both genes. We have also found that the deletion of any of these enhancers downregulates six well-known FOXP2 target genes in the SK-N-MC cell line.

Conclusions: We expect these findings contribute to a deeper understanding of how FOXP2 and MDFIC are regulated to pace neuronal development supporting cognition, speech and language.
\end{abstract}

Keywords: FOXP2, MDFIC, Speech and language impairment, Spanish, CRISPR-genome editing, Functional enhancers, Chromosomal rearrangement

\section{Background}

Mutations in the coding region of the FOXP2 gene, encoding a forkhead transcription factor, are known to cause speech and language impairment [1-6]. Polymorphisms of the gene have also been associated with schizophrenia [7](Tolosa et al., 2010) and frontotemporal lobar degeneration [8]. FOXP2 has been hypothesised to regulate the development and function of brain areas involved in language processing $[1,9,10]$, because of its known role in neurogenesis, neuron differentiation, and neuron migration in the developing telencephalon of mice [11-13]. Pathogenic mutations in humans have proven to impair auditory-motor association learning when mimicked in mice [14]. Nonetheless, the exact role of FOXP2 in normal development of the human brain and cognition is unknown. Common variants of the gene

\footnotetext{
* Correspondence: abenitez8@us.es

†Sandra Rodríguez-Perales and Paloma García-Bellido contributed equally to this work.

${ }^{2}$ Department of Spanish, Linguistics, and Theory of Literature (Linguistics), University of Seville, Seville, Spain

Full list of author information is available at the end of the article
}

do not contribute appreciably to individual differences in language development [15], nor in brain structure [16], although a FOXP2 polymorphism has been recently associated with enhanced procedural learning of non-native speech sound categories [17]. Less is known about how the expression of the gene is modulated. The promoter of FOXP2 contains four transcription start sites [18], with multiple alternative splicing sites [19]. FOXP2 also contains six ultraconserved regions in its introns [18], as well as six predicted enhancers for lef1 [20], a transcription factor that drives expression of foxP2 in the central nervous system during zebrafish embryogenesis [21]. Interestingly, several microRNAs bind the 3'UTR of the FOXP2 gene and regulate the expression of the gene [22].

Pathogenic microdeletions involving the FOXP2-MD$F I C$ region resulting in language or cognitive impairment have been reported (Additional file 1: Figure S1). Most microdeletions have removed partially the 3 ' end of the FOXP2 gene, likely resulting in altered expression levels of FOXP2 and/or shorter aberrant FOXP2 proteins. It 
has been recently reported on a young female, harbouring a de novo balanced complex rearrangement involving one copy of chromosomes 7 and 11, who presents with a severe developmental expressive and receptive speech and language impairment in two language modalities: Castilian Spanish and Valencian [23]. The rearrangement of this clinical case does not interrupt any protein-coding sequence in derivative chromosomes 7 or 11, and no other protein-coding gene, close to the regions interrupted by the rearrangement except FOXP2, is considered to be a strongly suspected candidate for the phenotype observed [23]. Although the FOXP2 coding region is intact, the breakpoint in $7 \mathrm{q} 31.1$ is located $205.5 \mathrm{~kb}$ downstream the $3^{\prime}$ end of FOXP2, suggesting that it might have affected some regulatory region of the gene. Based on FISH results from the RP11-243D16 BAC, it has been proven that in this proband FOXP2 is de novo rearranged to derivative chromosome 11p [23]. Becker and collaborators [24] identified and characterized in a luciferase assay a functional enhancer located $2.5 \mathrm{~kb}$ downstream the breakpoint, here FOXP2-E $\mathrm{E}^{\text {distal }}$, and hypothesized that separating this putative regulatory element from the coding region of FOXP2 would have contributed to the observed language phenotype by disturbing FOXP2 gene expression. The putative gene-specific regulatory role of this characterised element needed to be tested.

The development of nuclease mediated genome editing tools, specially, of those based on clustering regularly interspaced short palindromic repeats (CRISPR) [25-27], has emerged as an efficient way of inducing targeted chromosomal deletions and an accurate method to validate the functionality of enhancers $[28,29]$. Here we report a detailed functional study of the intergenic region between FOXP2 and MDFIC genes. It has been found that this region contains, apart from the enhancer found in Becker's report [24], another functional enhancer, here FOXP2-E proximal. We performed a targeted deletion of one regulatory element per cell by CRISPR-Cas 9 and found that whereas FOXP2's mRNA and protein levels decreased, MDFIC's mRNA and protein levels increased. We hypothesise that the breakpoint in chromosome $7 \mathrm{q} 31.1$ of the proband [23] may have disrupted this intergenic regulatory region causing, anomalously, FOXP2 to be downregulated and MDFIC upregulated. Changes in the expression levels of these two adjacent protein-coding genes in particular brain circuits during development may have led to the observed language deficits in the proband. We expect these findings contribute to a better understanding of how FOXP2 is regulated.

\section{Methods}

\section{Cell culture and electroporation}

HEK293 (CRL-1573, ATCC, USA) and SK-N-MC (HTB-10, ATCC, USA) cells were cultured in Dulbecco's modified Eagle's medium (DMEM) (Lonza) using standard conditions: DMEM medium was supplemented with $10 \%$ foetal bovine serum (FBS) (Life Tech), 1\% GlutaMAX (Life Tech) and 100 units/ml penicillin/streptomycin (Life Tech). Cells were cultured at $37^{\circ} \mathrm{C}$ in a humidified atmosphere of $5 \% \mathrm{CO}_{2}+20 \% \mathrm{O}_{2}$. Cells were passed when they reached at $80 \%$ of confluence.

SK-N-MC and HEK293 cells were electroporated with $2 \mu \mathrm{g}$ of either pLV-U6 ${ }^{\# \mathrm{x}}-\mathrm{C} 9 \mathrm{G}, \mathrm{pLV}-\mathrm{U} 6^{\# \mathrm{x}} \mathrm{H} 1^{\# \mathrm{y}}{ }_{-} \mathrm{C} 9 \mathrm{G}$ or with an empty plasmid. For electroporation, we used the Neon Transfection System (Life Technologies) as previously described [30]. The manufacturer's protocols for HEK293 and SK-N-MC cells were modified as follows. Cells were trypsinized and resuspended in $\mathrm{R}$ solution (Life Technologies). For SK-N-MC 10- $\mu$ lips were used to electroporate $2.5 \times 10^{5}$ cells with a single 50 -ms pulse of $900 \mathrm{~V}$. For HEK293 cells, $4 \times 10^{5}$ cells were electroporated with $10-\mu \mathrm{l}$ tips using three $10-\mathrm{ms}$ pulses of $1245 \mathrm{~V}$. After electroporation, cells were seeded in a 24-well plate containing pre-warmed medium. When required, cells were sorted $72 \mathrm{~h}$ post-transfection.

\section{sgRNA design and construction of single- and double- guide Cas9-encoding plasmids}

The CRISPR sgRNAs were designed using the http:// crispr.mit.edu/ and https://benchling.com/ online tools that were also used to evaluate their off-target scores. The parental pLV- $\mathrm{U}^{\# \mathrm{x}}$-C9G and $\mathrm{pLV}-\mathrm{U} 6^{\# \mathrm{x}} \mathrm{H} 1^{\# \mathrm{y}}$-C9G vector has been described elsewhere [31]. Eight gBlocks gene fragments (IDT) were synthesized to clone the sgRNAs separately or in the following combinations sgEp\#1-sgEp\#3, sgEp\#1-sgEp\#4, sgEp\#2-sgEp\#3, sgEp\#2sgEp\#4, sgEd\#1-sgEd\#3, sgEd\#1-sgEd\#4, sgEd\#2-sgEd\#3 or sgEd\#2-sgEd\#4 (Additional file 7: Table S1), flanking the FOXP2-E ${ }^{\text {proximal }}$ and FOXP2-E ${ }^{\text {distal }}$ enhancer regions in the backbone vector using BsrGI and SpeI target sites.

\section{TIDE assay}

$72 \mathrm{~h}$ post-electroporation genomic DNA was extracted using DNeasy blood and tissue kit (QIAGEN) following manufacturer's instructions. 300-500 bp PCR amplicons spanning the sgRNA genomic target sites were generated using the primers shown in Additional file 7: Table S1. PCR products were purified with QIAquick PCR purification kit (QIAGEN) and Sanger-sequenced using both PCR primers and each sequence chromatogram was analysed with the online TIDE software available at http:// tide.nki.nl. Analyses were performed using a reference sequence from a control cell sample electroporated with the pLV-U6H1-C9G empty vector. Parameters were set to the default maximum indel size of 10 nucleotides and the decomposition window to cover the largest possible window with high quality traces. All TIDE analyses below the detection 
sensitivity of $3.5 \%$ were considered as non-significant targeted [32, 33].

\section{Flow cytometry and cell sorting}

$72 \mathrm{~h}$ after electroporation, cells were trypsinized, counted, and resuspended at the concentration of 3-5 $\times$ $10^{6}$ cells $/ \mathrm{ml}$ in an appropriate volume of sorting buffer (phosphate-buffered saline (PBS)/0.5\% bovine serum albumin (BSA)/2 mM EDTA and 100 units/ml penicillin/ streptomycin (Life Technologies)) for flow cytometry analysis. Immediately before cell sorting, samples were filtered through a $70-\mu \mathrm{m}$ filter (Miltenyi Biotec) to remove any clumps or aggregates. Sorting was performed in sterile conditions throughout the experiments in the sorting buffer described above recovering at least $0.5 \times$ $10^{6}$ cells per experimental condition. Cell sorting was carried out in a Synergy $2 \mathrm{~L}$ instrument (Sony Biotechnology Inc.); flow cytometry was performed in a BD LSR Fortessa analyzer (BD Biosciences) and FACSDiva software was used. Proper electronic gates of side scatter and forward scatter parameters were set in order to exclude cell debris and dead cells. The SK-N-MC or HEK293 GFP negative control cells were analysed in order to assess the minimal fluorescein isothiocyanate baseline. Sorting was performed in sterile conditions throughout the experiment. Sorted cells were seeded individually per well in a 96 well-plate containing DMEM supplemented medium.

\section{Genomic DNA extraction and PCR analysis}

Standard procedures were used for genomic DNA extraction $72 \mathrm{~h}$ post-electroporation [31]. Briefly, $10 \times 10^{6}$ cells were lysed in $100 \mathrm{mM} \mathrm{NaCl}$, Tris (pH 8.0) $50 \mathrm{mM}$, EDTA $100 \mathrm{mM}$, and 1\% SDS followed by overnight digestion with $0.5 \mathrm{mg} / \mathrm{ml}$ of proteinase $\mathrm{K}$ (Roche Diagnostics) at $56^{\circ} \mathrm{C}$. Afterward, the DNA was cleaned by $\mathrm{NaCl}$ precipitation, precipitated with isopropanol and resuspended in 1xTE buffer. NanoDrop ND 1000 Spectrophotometer (NanoDrop Technologies) was used to quantified DNA.

For deletion analysis and homozygous versus heterozygous representation standard PCR and three primer strategy analysis were performed in a Veriti 96-well Thermal Cycler (Applied Biosystems) under the following conditions: $95^{\circ} \mathrm{C}$ denaturation for $1 \mathrm{~min}$ followed by 30 cycles of denaturation at $94^{\circ} \mathrm{C}$, annealing at $62.5^{\circ} \mathrm{C}$, extension at $72^{\circ} \mathrm{C}$, and a final extension at $72^{\circ} \mathrm{C}$. Primers used are described in Additional file 7: Table S1.

\section{RNA extraction and qRT-PCR}

Trizol (Sigma-Aldrich) protocol followed by RNase-free DNAse (Roche Applied Science) treatment was used to extract total RNA from cell cultures. $500 \mathrm{ng}$ of total RNA was used for cDNA synthesis using the Superscript
III First Strand cDNA Synthesis Kit (Life Tech). Quantitative real-time PCR was performed on an ABI Prism 7900 HT Detection System (Applied Biosystems) with SDS 2.1 software. The reaction mix contained TaqMan master mix (Thermo Fisher) and $0.3 \mu \mathrm{M}$ of each primer (Additional file 7: Table S1). Cycling conditions were 50 ${ }^{\circ} \mathrm{C}$ for $2 \mathrm{~min}$ and $95^{\circ} \mathrm{C}$ for $3 \mathrm{~min}$, followed by 40 cycles at $95^{\circ} \mathrm{C}$ for $15 \mathrm{~s}$ and $58^{\circ} \mathrm{C}$ for $45 \mathrm{~s}$, and, finally, $95^{\circ} \mathrm{C}$ for $15 \mathrm{~s}, 60^{\circ} \mathrm{C}$ for $20 \mathrm{~s}$, and $95^{\circ} \mathrm{C}$ for $15 \mathrm{~s}$.

PCR was performed in 96-well plate microtest plates. In all experiments, hGAPDH (internal reference control) was used to normalize mRNA amounts to the total amount of cDNA. Each sample was determined in triplicate, and three independent samples were analysed for each experimental assay.

\section{Western blot}

Proteins were extracted by standard procedures as previously described [34] in the presence of Complete Protease Inhibitor Cocktail Tables (Roche Applied Science). Control cells are SK-N-MC electroporated with the pLV-U6 ${ }^{\#} \mathrm{H1}^{\#}$-C9G plasmid. Proteins were wet-transferred with TransFi (Invitrogen; Life Technologies) to polyvinyl difluoride (PVDF) membranes (Hybond-P, Amersham Biosciences) for $90 \mathrm{~min}$. The protein-bound membranes were blocked with non-fat dry milk in Tris-buffered saline with Tween-20 at room-temperature and then incubated overnight at $4{ }^{\circ} \mathrm{C}$ with monoclonal mouse anti-human FOXP2 or MDFIC antibodies $(1 / 1000$ or $1 / 500$; BD Pharmigen) or with rabbit anti-human GAPDH antibody (1/500; AbCam). After several PBS-T washes the membranes were incubated for $1 \mathrm{~h}$ at room temperature with secondary antibodies horseradish peroxidase (HRP)-conjugated with goat anti-mouse (1/1000) and goat anti-Rabbit (1/500; Dako, Barcelona, Spain) diluted in PBS-T. After several PBS-T washes the membranes were developed with enhanced chemiluminiscence (ECL) (GE Healthcare). The ECL signals were visualized on X-ray films. The FOXP2 and MDFIC proteins were normalized with the GAPDH internal control in the same lane.

\section{Statistical analysis}

Data from three independent experiments were analysed by two-tailed Student's t-test using Excel (Microsoft). All data are expressed as means \pm s.e.m. $P<0.05$ was considered statistically significant. ${ }^{*} p<0.05$; ${ }^{* * *} p<0.01$; $* * *$ $p<0.001$; and ${ }^{* * * * *} p<0.0001$.

\section{Results}

\section{In silico search of enhancer regions}

We first hypothesised that the breakpoint in $7 \mathrm{q} 31.1$ (chr7:114,888,284 hg38 equivalent to $114,539,340$ hg19) affected the expression of FOXP2 by physically 
disrupting a regulatory region downstream the coding region of the gene containing cis-acting distant elements with an enhancer role (Fig. 1a). Accordingly, we used the Encyclopedia of DNA Elements (ENCODE, https:// genome.ucsc.edu/ENCODE/) to perform in silico searching for putative enhancers in the intergenic region between FOXP2 and MDFIC. We looked for the following hallmarks from ENCODE: DNase I hypersensitive sites, presence of histones with specific post-translational modifications (in particular, histone $\mathrm{H} 3$, lysine 4 monomethylation (H3K4Me1) and H3 lysine 27 acetylation (H3K27Ac)), and regions recruiting co-activators and co-repressors as revealed by chromatin immunoprecipitation followed by deep sequencing (ChIP-seq) (Fig. 1b). The ENCODE data, derived from a large collection of different cell types, including hippocampal cells, cerebellar cells, and cells from the spinal cord, showed two putative enhancers located at $120 \mathrm{~kb}$ and $208 \mathrm{~kb}$ downstream the stop codon of FOXP2, respectively (Fig. 1b). These putative enhancers (referred

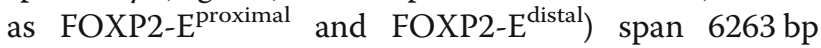
(chr7:114,817,431-114,823,694 hg38 equivalent to $114,456,873-114,463,136 \quad \mathrm{hg} 19)$ and $2313 \mathrm{bp}$ (chr7:114,900,989-114,903,302 hg38 equivalent to 114,541,370-114,543,683 hg19), respectively. FOXP2-E ${ }^{\text {distal }}$ is the one previously validated by lucifer-

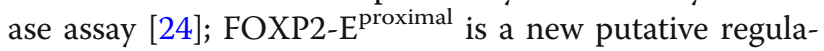
tory element.

\section{CRISPR-Cas9 deletion of FOXP2-E ${ }^{\text {proximal }}$ and FOXP2- E $^{\text {distal }}$}

Deletion of an enhancer motif provides direct evidence for enhancer activity, CRISPR-Cas9 being the gold standard to study its role in the regulation of endogenous gene transcription. To investigate the regulatory role of FOXP2-E $E^{\text {proximal }}$ and FOXP2-E $E^{\text {distal }}$, we specifically deleted the entire predicted sequence of one or another of the two putative enhancers in a cell line of neuroectodermal human origin. Previous attempts to measure FOXP2 expression in primary skin fibroblasts from the proband failed because mRNA levels were too low for significant statistical analysis [23]. Expression levels of MDFIC mRNA, obtained by Affymetrix gene expression arrays from primary skin fibroblast from the proband, were found to be higher than those of FOXP2, but were not independently validated ([23], Additional file 5: Table S5). SK-N-MC neuroblastoma cells derive from the supraorbital area and express FOXP2 and MDFIC constitutively. To generate a specific deletion we relied on a CRISPR-Cas9 genome editing approach. In our strategy, two independent pairs of sgRNAs are used to target the flanking regions of either FOXP2- $\mathrm{E}^{\text {proximal }}$ or FOXP2-E $\mathrm{E}^{\text {distal }}$ to induce repair of the resultant two double strand breaks (DSBs) by non-homologous end-joining (NHEJ) with deletion of the intervening segment (Fig. 1c). First, two sgRNAs were designed per flanking region (eight in total, Additional file 7: Table S1) and cloned them separately in the $\mathrm{pLV}-\mathrm{U6}^{\# \mathrm{x}}-\mathrm{C} 9 \mathrm{G}$ vector [31] in order to analyse their specificity and efficiency of cleavage. SK-N-MC cells were electroporated with one of the $\mathrm{pLV}-\mathrm{U} 6^{\# \mathrm{x}}$-C9G single sgRNA expression vectors to precisely determine the on-target (efficiency) and off-target (specificity) DNA modification frequencies in the pooled edited cell population by tracking of indels by decomposition (TIDE) assay [32]. As shown in Additional file 2: Figure S2 the on-target cleavage efficiencies, measured by INDEL frequency, ranged from 3.9 to $17.1 \%$ whereas no significant off-target activity was observed at the predicted top off-target sites (Additional file 3: Figure S3). The four flanking sgRNAs, two for each deletion, with the highest cleavage efficiencies were selected and cloned by pairs in the pLV- $U 6^{\# \mathrm{x}} \mathrm{H} 1^{\# \mathrm{y}}$-C9G [31] in order to couple its expression with Cas9 nuclease and GFP reporter generating the $\quad \mathrm{pLV}-\mathrm{U} 6^{\# 1} \mathrm{H} 1^{\# 4}-\mathrm{C} 9 \mathrm{G}-\mathrm{E}^{\text {proximal }}$ and pLV-U6 ${ }^{\# 2} \mathrm{H}^{\# 4}$-C9G- $\quad \mathrm{E}^{\text {distal }} \quad$ vectors. $\quad 72 \mathrm{~h}$ post-nucleofection with the double-guide or empty pLV-U6 ${ }^{\#} \mathrm{H1}^{\#}$-C9G control vector PCR analyses of the SK-N-MC bulk cell populations confirmed the deletion of the $6.2 \mathrm{~kb}$ or the $2.3 \mathrm{~kb}$ expected fragments (Figs. 1c and 2a-left panel). Sanger sequence analysis confirmed the presence of the deletions (Fig. 2b). We then generated five FOXP2- $E^{\text {proximal }}$ and three FOXP2- $E^{\text {distal }}$ deleted clonal cell lines, by sorting GFP positive cells into 96-well plates and allowing for single cell colony expansion. A three primer PCR approach confirmed higher rates of homozygous compared to heterozygous clones. The five FOXP2- $\mathrm{E}^{\text {proximal }}$ deleted clones harboured a homozygous deletion, whereas only one of three FOXP2-E ${ }^{\text {distal }}$ deleted clones harboured a heterozygous deletion (Additional file 4: Figure S4 bottom panels). PCR analysis revealed that two out of the five FOXP2-E $E^{\text {proximal }}$ clonal cell lines having harboured the deletion also contained small insertion/deletions produced at CRISPR recognition sites and consequently were excluded from our study (Data not shown). Interestingly, clones with homozygous deletion could readily be isolated, but only one heterozygous clone could be obtained. This is potentially due to the efficiency of the Cas9 to perform genome engineering which results mostly in bi-allelic edition $[28,35-38]$. SK-E ${ }^{\text {prox }}-1$, SK-E $E^{\text {prox }}-2$ and SK-E ${ }^{\text {prox }}-3$ homozygous clones, SK- dis $_{-1}-1$ heterozygous and SK-E ${ }^{\text {dis }}-2$ and SK-E ${ }^{\text {dis }}-3$ homozygous clones were selected for further analysis.

To test whether the FOXP2- $\mathrm{E}^{\text {proximal }}$ and/or FOXP2-E ${ }^{\text {distal }}$ regions play a functional role in other cell types, we deleted one predicted enhancer per non-neuronal HEK293 cell. HEK293 cells have been used previously to show functionality of the 


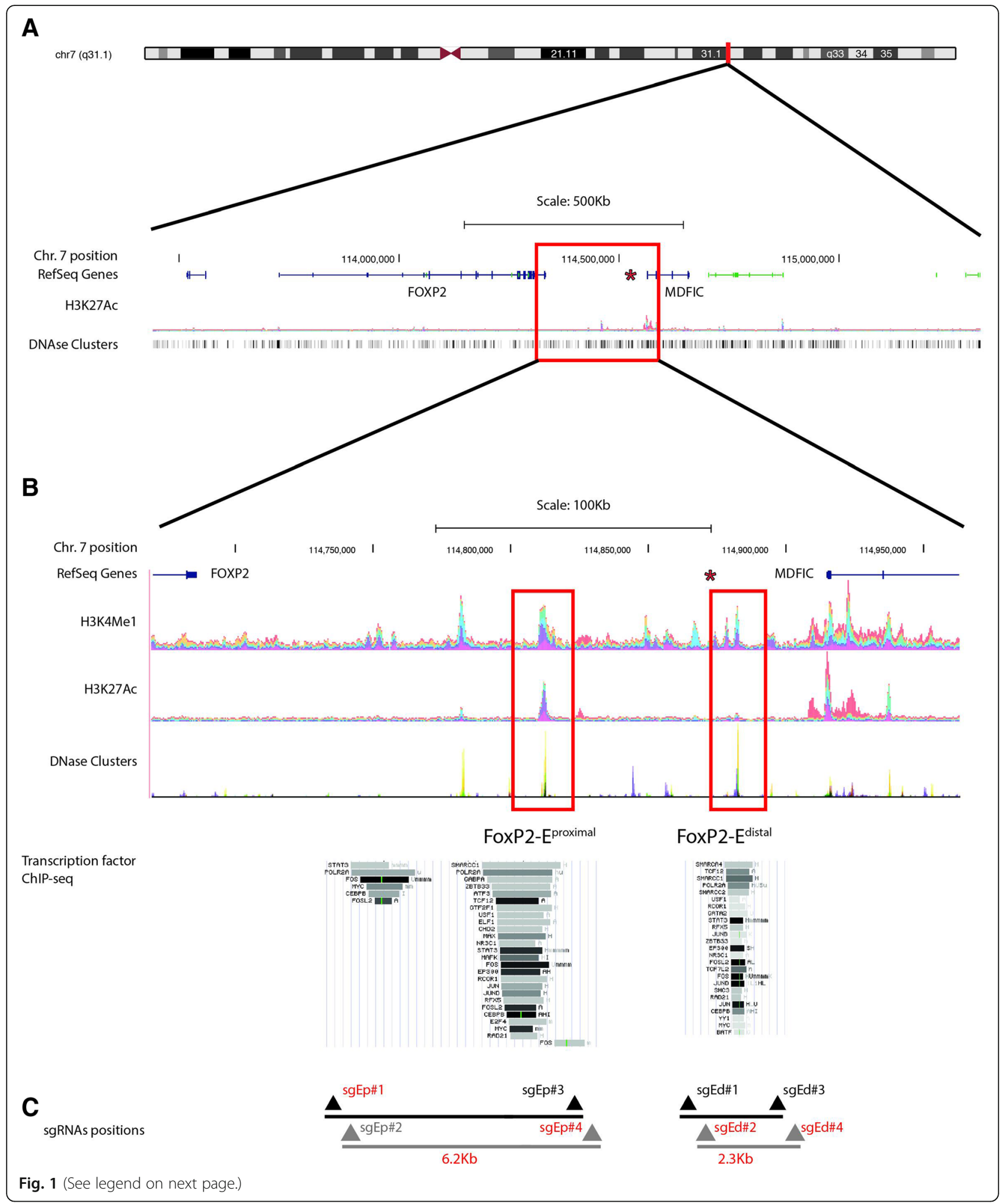


(See figure on previous page.)

Fig. 1 Identification of enhancer regions downstream FOXP2 and upstream MDFIC. a. Genomic location of human FOXP2 and MDFIC genes (GRCh38/hg38). The red asterisk shows the intergenic position of the $7 q 31.1$ breakpoint in the proband harbouring a genomic complex rearrangement of intact FOXP2 and with severe expressive and receptive speech and language impairment. $\mathbf{b}$. Detailed view of an ENCODE UCSC genome-browser snapshot showing bar graphs with a detailed representation of the locations of H3K4Me1 and H3K27Ac histone marks and DNA clusters in human cell lines. The squared regions in red show the locations of FOXP2-Eroximal and FOXP2-E ${ }^{\text {distal }}$. The red asterisk shows the position of the $7 \mathrm{q}$ breakpoint in the proband harbouring a genomic complex rearrangement and with severe expressive and receptive speech and language impairment. The transcription factor track shows transcription factor binding sites obtained from a collection of ChIP-seq experiments. A grey horizontal box (32 for FOXP2-E proximal and 25 for FOXP2-E ${ }^{\text {distal }}$ ) encloses each transcription factor cluster, with the darkness of the box being proportional to the maximum signal strength. The transcription factor name is shown to the left of each box. As seen in the figure the majority of transcription factors bind to both enhancers. c. Schematic representation of the location of the four sgRNA pairs flanking the $6.2 \mathrm{~kb}$ region including FOXP2-E $\mathrm{E}^{\text {proximal }}$ and the $2.3 \mathrm{~kb}$ region including FOXP2-E ${ }^{\text {distal }}$. sgRNAs with the highest cleavage efficiencies are labelled in red

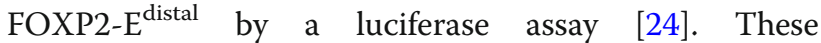
easy-to-transfect cells, have been extensively used as a quick and straightforward system to characterize gene function and enhancer prediction [39-41]. HEK293 cells were nucleofected with either $\mathrm{pLV}-\mathrm{U} 6^{\# 1} \mathrm{H} 1^{\# 4}-\mathrm{C} 9 \mathrm{G}-\mathrm{E}^{\text {proxi- }}$ mal, pLV-U6 ${ }^{\# 2} \mathrm{H} 1^{\# 4}-\mathrm{C} 9 \mathrm{G}-\mathrm{E}^{\text {distal }}$ vectors or with an empty pLV-U6 ${ }^{\#} \mathrm{H} 1^{\#}$-C9G control plasmid. $72 \mathrm{~h}$ post-transfection PCR analysis revealed targeted deletion of the 6.2 $\mathrm{kb}$ or the $2.3 \mathrm{~kb}$ regions, which contain the entire sequence of FOXP2-E Eroximal $^{\text {or FOXP2-E }}$ distal $^{\text {, respectively }}$ (Fig. 2a right panel). Accordingly, we were able to generate 8 homozygous and 6 heterozygous clonal FOXP2-E proximal $^{\text {; }}$ and 15 homozygous FOXP2- $E^{\text {distal }}$ deleted cell lines by sorting GFP positive cells and single cell colony expansion (Additional file 4: Figure S4 upper panels). PCR analysis confirmed the deletion of either the FOXP2- $\mathrm{E}^{\text {proximal }}$ or the FOXP2- $\mathrm{E}^{\text {distal }}$ elements (Fig. 2a-right panel). A three-primer PCR approach was used to analyse the homo or heterozygous deletion status (Additional file 4: Figure S4 upper panels) and the HEK- $\mathrm{E}^{\text {prox }}-1$ homozygous, HEK- $\mathrm{E}^{\text {prox }}-2$ heterozygous and HEK-E $E^{\text {prox }}-3$ heterozygous, HEK- $E^{\text {dis }}-1$, HEK-E ${ }^{\text {dis }}-2$ and HEK-E ${ }^{\text {dis }}-3$ homozygous clones were selected for further analysis.

\section{FOXP2 and MDFIC expression analyses}

We next aimed to characterize in more detail the regulatory expression pattern of FOXP2-E proximal $^{\text {and }}$ FOXP2-E ${ }^{\text {distal }}$. Since both putative enhancers are located in an intergenic region, we aimed at characterizing that each of them is functional with respect to their flanking genes, FOXP2 or MDFIC. We used Western blot analysis to test the amount of FOXP2 and MDFIC proteins in the SK-N-MC pooled cell clones harbouring either the FOXP2-E ${ }^{\text {proximal }}$ or FOXP2-E $\mathrm{E}^{\text {distal }}$ deletions, and also in control cells electroporated with the pLV-U6 ${ }^{\#} \mathrm{H1}^{\#}$-C9G empty plasmid (Fig. 2c). The deletion of FOXP2- $\mathrm{E}^{\text {proximal }}$ or FOXP2- $\mathrm{E}^{\text {distal }}$ was found to reduce the amount of the FOXP2 protein (Fig. 2c top) and to increase the amount of MDFIC (Fig. 2c bottom). A decreasing FOXP2 protein effect was found to be more pronounced in the SKN-M-C cells with a FOXP2-E ${ }^{\text {prox- }}$ imal deletion than with a FOXP2-E distal removal.

We used qRT-PCR to determine the amount of FOXP2 mRNA in the SK-N-MC cells harbouring either FOXP2-E ${ }^{\text {proximal }}$ or FOXP2-E ${ }^{\text {distal }}$ deletions, or a control empty pLV-U6 ${ }^{\#} \mathrm{H} 1^{\#}$-C9G line with a wild type genotype. The analysis of three independent homozygous clones showed a significant reduction (up to 2 fold change) in the mRNA expression of FOXP2 compared to that of the control cells when FOXP2- $\mathrm{E}^{\text {proximal }}$ was deleted (Fig. 2d, up). Likewise, FOXP2 mRNA expression was decreased (up to 2 fold change) in three SK-N-MC clones when FOXP2-E ${ }^{\text {distal }}$ was deleted either in homozygous or in heterozygous clones (Fig. 2d up). We then measured the expression levels of MDFIC in SK-N-MC clones after the deletion of each enhancer. As shown in Fig. 2d-down, the expression of MDFIC was significantly increased when either FOXP2- $\mathrm{E}^{\text {proximal }}$ or FOXP2- $\mathrm{E}^{\text {distal }}$ were deleted (up to 9.5 and 11 fold change, respectively).

To further investigate the neuronal specificity of FOXP2- $E^{\text {proximal }}$ or the FOXP2-E ${ }^{\text {distal }}$ enhancers, we replicated the experiment in randomly selected control HEK293 cell clones harbouring either the FOXP2-E ${ }^{\text {proximal }}$ or the FOXP2-E $E^{\text {distal }}$ deletions or in a control cell line electroporated with the pLV-U6 ${ }^{\#} \mathrm{H}^{\#}$-C9G vectors. The engineered HEK293 cells do not exhibit significant alteration of the FOXP2 or MDFIC mRNA expression, compared to the parental HEK293 cells (Additional file 5: Figure S5). We noted that SK-N-MC cells are derived from a neurologic origin whereas HEK293 cells are derived from the kidney. Therefore, MDFIC and FOXP2 regulation of expression and post-transcriptional processes are likely to be different in the two cell types; as expected the changes in the expression of both genes in the SK-N-MC and HEK293 cells upon deletion of FOXP2-E Eroximal $^{\text {and }}$ FOXP2-E $E^{\text {distal }}$ were different. While in a SK-N-MC cell line deletion of each enhancer has a statistically significant effect by decreasing mRNA transcription levels of FOXP2 and increasing the levels of $M D F I C$, this effect is of no statistical significance in a HEK 293 cell line (Fig. 2d and Additional file 5: Figure S5). These results indicate that 

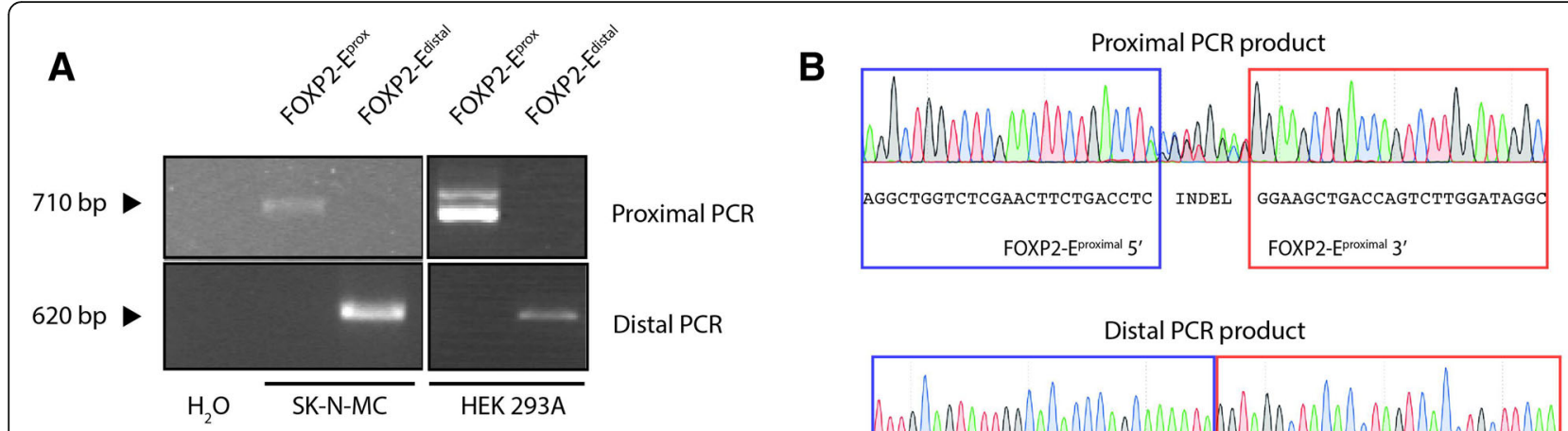

Proximal PCR product

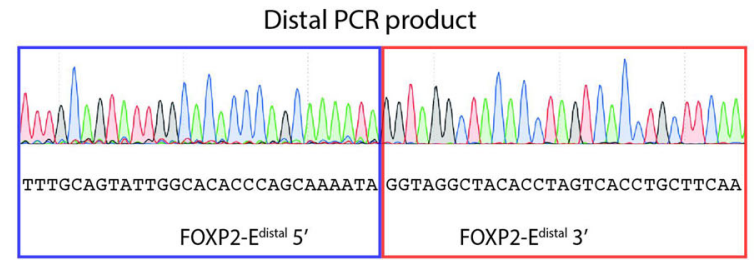

C

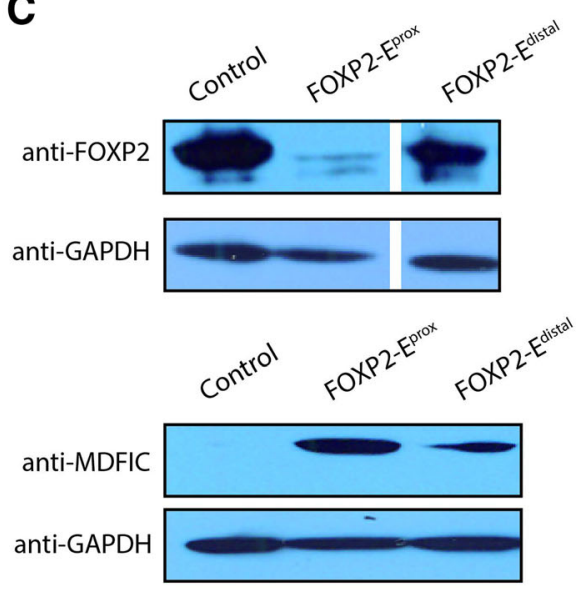

D
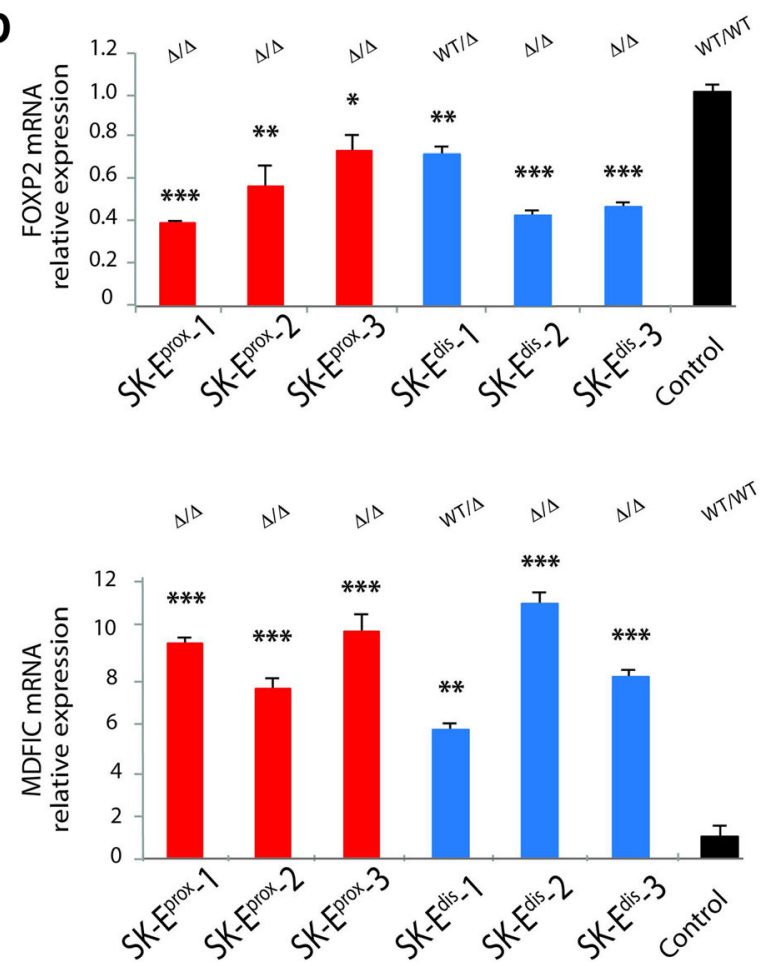

Fig. 2 Molecular characterization of FOXP2-Eproximal and FOXP2-Edistal a. PCR analysis. Two oligos flanking the deleted regions were used to

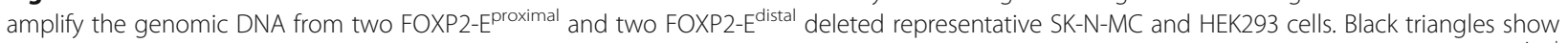
the size of the PCR products. $\mathbf{b}$. Representative Sanger sequencing chromatogram showing the sequences of the junctions of the FOXP2-E (top) and FOXP2-E ${ }^{\text {distal }}$ (bottom) genomic deleted regions in a SK-N-MC cells. c. Western blot analysis of cell lysates of SK-N-MC with FOXP2$E^{\text {proximal }}$ deleted, with FOXP2-Edistal deleted, and of SK-N-MC control cells electroporated with pLV-U6 ${ }^{\#} 1^{\#}$-C9G plasmid for FOXP2 (top) or MDFIC

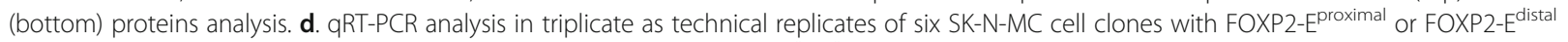
deletions, control cells are SK-N-MC cells electroporated with the PLV-U6\# ${ }^{\#} 1^{\#-C 9 G}$ plasmid. Both deleted and control values are normalized to those of the internal reference gene hGUSB. Levels of expression of FOXP2 (up) and MDFIC (down) are represented by the fold change relative to that of empty vector control cell line, which was normalized to 1. Data from three or more independent experiments were analysed by twotailed unpaired t-test. NS, non-significant; ${ }^{*} p<0.05 ;{ }^{* *} p<0.01$; ${ }^{* *} p<0.001$; and ${ }^{* * *} p<0.0001$

the interacting promoters are, potentially, significantly co-expressed in a tissue-specific manner.

Knowing that FOXP2 is a transcription factor that leads to significant changes in the transcription of specific target genes, we tested whether the downregulation of FOXP2 expression after FOXP2-E proximal $^{\text {or }}$ FOXP2-E ${ }^{\text {distal }}$ was coupled with alterations in the expression level of six well-known FOXP2 target genes: 
CALCRL, CRH, EPOR, MAPK8IP1, PM5, and SYK [42, 43]. Cells transfected with empty pLV-U6 $6^{\#} \mathrm{H}^{\#}$-C9G plasmid were used as a baseline control for comparison. Real-time quantitative RT-PCR (qRT-PCR) on total RNA extracted from the six SK-N-MC cellular clones described above demonstrated that the six FOXP2 target genes have a significant downregulation in mRNA expression (Fig. 3). These results reinforce the view that each, FOXP2-E proximal and FOXP2-E distal $^{\text {, significantly }}$ regulates the expression of FOXP2 and that of six FOXP2 target genes in a human neuronal cell line.

\section{Discussion}

In this paper we have characterised in detail the role of two functional regulatory elements located downstream FOXP2 employing a CRISPR-Cas9 approach in a neuronal cell line. ENCODE Encyclopedia data suggested that two putative enhancers are localized in the intergenic region between FOXP2 and MDFIC, located at $120 \mathrm{~kb}$ and $208 \mathrm{~kb}$ downstream the stop codon of
FOXP2. FOXP2-E ${ }^{\text {distal }}$ had been previously found to be functional in an overexpression luciferase assay [24], whereas FOXP2-E Eroximal $^{\text {was }}$ previously uncharacterized. Using CRISPR-Cas9 approach we could readily isolate clones with homozygous deletion, but, interestingly, only a very low number of heterozygous clones could be isolated, possibly due to the efficiency of Cas9 nuclease [44]. We have now proved that if FOXP2- $E^{\text {distal }}$ is deleted, FOXP2 becomes downregulated and the levels of FOXP2 protein are reduced in the SK-N-MC neuroblastoma cells. We have further proved that, if FOXP2-Edistal is deleted, it also affects the expression of the adjacent downstream gene, $M D F I C$, by increasing its mRNA and protein levels. We have found that FOXP2-E ${ }^{\text {proximal }}$ deletion, as that of FOXP2-E $E^{\text {distal }}$, downregulates FOXP2 and upregulates $M D F I C$, decreasing protein levels of FOXP2 and increasing those of MDFIC. Although each element deletion induces a significant decrease in the levels of mRNA expression of FOXP2, this reduction seems to be higher at the protein level for

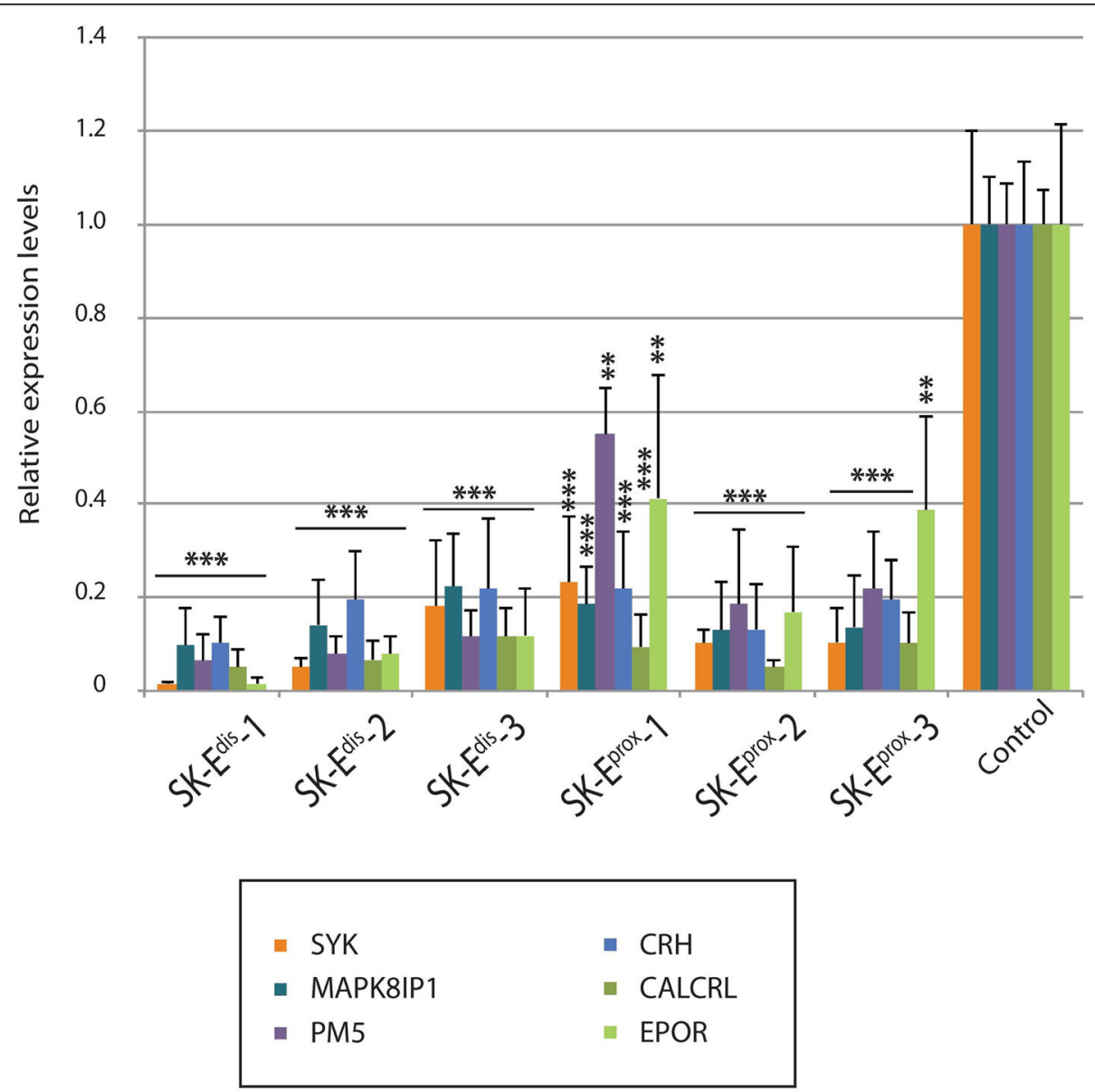

Fig. 3 Graphical representation of qRT-PCR analysis of SYK, MAPK8IP1, PM5, CRH, CALCRL and EPOR FOXP2 target genes in SK-N-MC FOXP2$E^{\text {proximal }}$ or FOXP2-Edistal enhancers deleted cells and control SK-N-MC cell electroporated with the pLV-U6 ${ }^{\sharp x} \mathrm{H} 1^{\# y}-C 9 G$ empty vector. $n=3$. mean \pm s.e.m. ${ }^{*} P=0.01-0.05,{ }^{* *} P=0.001-0.01,{ }^{* * *} P=0.001-0.0001$, unpaired two-tailed Student's t-test 


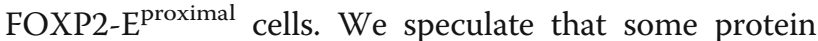
regulatory mechanisms would be involved but what exactly these mechanisms are is poorly understood. Our results, in line with recent massive data derived from next-generation DNA sequencing and proteomics, show a variation between mRNA and protein abundances. The observed variations between the FOXP2 protein amounts with its associated mRNA are probably due to the effect of post-transcriptional regulatory processes occurring after mRNA synthesis, translational and protein degradation regulations, controlling steady-state protein abundances [45]. We have demonstrated that the deletion of any one of the two enhancers, FOXP2-E $\mathrm{E}^{\text {proximal }}$ or FOXP2-E ${ }^{\text {distal }}$, leads to significant changes of FOXP2 expression and, interestingly, also in the transcription of six well-known FOXP2 target genes. These data support the hypothesis that each of the deleted regions functions as an expression regulator in a specific regulatory network of FOXP2 in a human cell line.

In the widely used HEK293 human cell line the expression of FOXP2 and MDFIC is also altered, but in a different manner, suggesting that each enhancer might confer a tissue specific regulation to each gene. Based on the results derived from HEK293 and SK-N-MC cell lines, FOXP2-E $\mathrm{E}^{\text {prox }}$ and FOXP2-E ${ }^{\text {distal }}$ elements appeared to affect FOXP2 and MDFIC promoters' activity in a cell-specific manner. This possibility is also reinforced by our finding that in the SK-N-MC line the six FOXP2 targets we have assessed are all downregulated after the deletion of any of these two enhancers, which suggests that FOXP2 is acting as an activator of gene expression. In other cell lines, like SH-SY5Y, some of these target genes (e.g. PM5) have been found to be downregulated by FOXP2 [42, 43].

One of the key processes in the enhancer-promoter interaction is mediated by transcription factors and their binding to enhancer and/or promoter regions, but chromatin structure and transcribed enhancer RNAs (eRNAs) from active enhancers also regulate enhancerpromoter looping and the release of paused RNAPII, and it is well established that these elements vary between cell types [46]. SK-N-MC is a neuroblastoma cell line derived from the supraorbital area, whereas HEK293 cells are derived from the kidney, therefore, chromatin structure regulatory element accessibility, signalling pathways, gene expression profiles and many other cell components are likely to be quite different in the two cell types. The exact causes of enhancer-promoter cell-type activity differences and their specific regulation in human cells are poorly understood and remain yet to be fully elucidated [47]. That said, because the cell lines we have selected for our study are known to have a long track of chromosomal aberrations, an induced pluripotent stem (iPS)-based replication of our findings should help to confirm this cell-specific effect we have uncovered.

The effect on FOXP2 and MDFIC gene expression regulation is coherent with previous studies reporting pairs of genes being governed by the same regulatory elements [48-50]. In some cases, these elements have proven to supercoil the DNA and to alter chromatin topology to facilitate or to hinder the assembly of the transcriptional machinery $[51,52]$. Our results indicate that whereas each enhancer deletion induced a downregulation on FOXP2 expression, MDFIC expression was significantly upregulated. One possible explanation for this phenomenon is that the deletion of FOXP2-E ${ }^{\text {prox }}$ or FOXP2-E ${ }^{\text {distal }}$ regulatory element could have removed or interfered with an inhibitory regulation process of MDFIC expression, maybe through an indirect modification of the chromatin structure. These data suggest that removal of any one of these two intergenic enhancers likely disables intricate inter-enhancer interactions [5356] which may be required to stabilize, within specific gene regulatory networks, gene-specific expression patterns in tissue-specific cell lines $[47,57]$.

FOXP2 is a well-known gene, important for speech and language $[6,58]$. Less is known about the role of $M D F I C$ in cognitive development and disease. This gene encodes a MyoD family inhibitor domain containing protein that acts as an activator or repressor of transcription $[59,60]$. Similarly to FOXP2, it interacts with LEF1, as part of beta-catenin regulation [61]. MDFIC is highly expressed in the cerebellum during human embryonic development and in the thalamus after birth (Human Brain Transcriptome http://hbatlas.org/). These two brain regions, interacting with others in a dopaminergic cortico-striato-thalamic loop, seem to play an important role in timing sensorimotor control, needed for auditory-motor language processing [1, 3, 10, 62].

Microdeletions affecting the FOXP2-MDFIC intergenic region have been reported to be associated with speech or cognitive impairment (Additional file 1: Figure S1). Most of these reported deletions encompass part of the coding region of FOXP2, and are confirmed or expected to involve some developmental language deficit. Interestingly, in one case entailing the deletion of FOXP2-E ${ }^{\text {distal }}$ only, coordination problems and learning disability have been reported (Additional file 1: Figure S1). Although this deletion encompasses the MDFIC gene, the reported phenotype recapitulates aspects of FOXP2 mutation or deletion. Because we have proven that the deletion of FOXP2-E ${ }^{\text {distal }}$ downregulates FOXP2 in a human neuronal cell line, we hypothesise that the speech and language deficits exhibited by our patient might result from the downregulation of FOXP2 [23]. Nonetheless, because the breakpoint also separated MDFIC from FOXP2-E $E^{\text {proximal }}$, we also expect the expression of 
MDFIC to be upregulated in our proband's brain cells. Additional studies should be conducted to prove or disprove our hypothesis. Interestingly, genomic rearrangements affecting topologically associating domains (TADs) can result in gene miss-expression and disease [50]. Genome engineering experiments aimed at deleting these two enhancers in other animal species could provide further support for their functionality. Bats seem a natural target, since they exhibit a learned vocal behaviour [63], these enhancer regions are conserved in most species (ENCODE data, Additional file 6: Figure S6), and gene delivery systems in the bat brain have been recently improved and tested with the FoxP2 gene [64]. The study of a specific neuronal brain cell line differentiated from iPS cells, obtained from our proband and a relevant control to implement genome editing, could contribute as well to give additional support to our hypothesis.

\section{Conclusions}

In summary, we expect that our findings, together with new available data about seed sequences of miRs in the 3'UTR region of FOXP2 [22, 65], contribute to a deeper understanding of how FOXP2 is regulated, and ultimately, of its role in the development of the biological machinery underlying language.

\section{Additional files}

Additional file 1: Figure S1. Genomic map of FOXP2 and MDFIC region. A. Chromosome 7 ideogram representation. Red box shows the region displayed below in Mb. B. Localization of FOXP2 (red track), MDFIC (yellow track), FOXP2-Eproximal and FOXP2-Edistal enhancers (green circles) and breakpoint locus (red asterisk). C. Deletions within the region of interest with a clinical significance as provided by DECIPHER (red tracks), showing the patients' identification number (red). The genomic coordinates according to the hg19 (black), and the most relevant clinical features (blue). ID, intellectual disability. (JPG $71 \mathrm{~kb}$ )

Additional file 2: Figure S2. Indel spectrum determined by TIDE of the on-target sites compared with indel frequencies of the control sample. Each module represents the TIDE analysis of one sgRNA in a bulk cell population electroporated with each of the single-guide-Cas 9 encoded plasmids. Each bar graph represents an indel event with an estimation of the percentage of the population exhibiting this particular event. Light-red bars represent the wild type control DNA sequence, bright-red bars represent significant indel events and black bars represent non-significant differences. $P$-values according to Pearson's chi-squared test. Decomposition was limited to indels of size $0-10$, hence larger indels could not be detected. R2 represent a quality measurement of the sequence reads. Indel $\%$ is represented at the top left site each module. (JPG $1103 \mathrm{~kb}$ )

Additional file 3: Figure S3. Indel spectrum determined by TIDE of the off-target sites compared with indel frequencies of the control sample. Each module represents the TIDE analysis of one sgRNA in a bulk cell population electroporated with each of the single-guide-Cas9 encoded plasmids. Each bar graph represents an indel event with an estimation of the percentage of the population exhibiting this particular event. Ontarget and potential off-target sequences are represented on top of each module and mismatched bases are shown in red. Light-red bars represent the wild type situation, bright-red bars represent significant indel events and black bars represent non-significant differences. P-values according to Pearson's chi-squared test. Decomposition was limited to indels of size $0-10$, hence larger indels could not be detected. R2 represent a quality measurement of the sequence reads. Indel \% is represented at the top left site each module. (JPG $1041 \mathrm{~kb}$ )

Additional file 4: Figure S4. PCR analysis. Two oligos flanking the deleted regions were used to amplify the genomic DNA from several mutant representative HEK293 and SK-N-MC clones. Black triangles show the size of the PCR products. Black or white asterisks show respectively the clones harbouring a homozygous or heterozygous deletion included in this study. M: molecular weight marker, WT/WT: wild type, $\Delta / \Delta$ : homozygous deletion, WT/ $\Delta$ : heterozygous deletion. (JPG $1181 \mathrm{~kb}$ )

Additional file 5: Figure S5. RT-qPCR analysis of six HEK293 cell clones with FOXP2-Eproximal or FOXP2-Edistal deletions. Samples are normalized to the average FOXP2 (left) or MDFIC (right) signal between three HEK293 replicates transfected with the pLV-U6 $6^{\# x} \mathrm{H} 1^{\# y}$-C9G empty vector. Levels of expression of FOXP2 and MDFIC are represented by the fold change relative to that of empty vector control cell line, which were normalized to 1 . WT/WT: wild type, $\Delta / \Delta$ : homozygous deletion, WT/ $\Delta$ : heterozygous deletion. (JPG $373 \mathrm{~kb}$ )

Additional file 6: Figure S6. Detailed view of an ENCODE UCSC genome-browser snapshot showing bar graphs with a detailed representation of the locations of FOXP2 and MDFIC genes, H3K27AC and DNA clusters in human cell lines. The squared regions in black show the locations of FOXP2-Eproximal and FOXP2-Edistal. The red squared tracks show the alignment result between humans and bats. (JPG $761 \mathrm{~kb}$ )

Additional file 7: Table S1. Oligonucleotide and sgRNA sequences used in this study. (DOCX $15 \mathrm{~kb}$ )

\section{Abbreviations}

CRISPR: Clustered regularly interspaced short palindromic repeats; eRNAs: enhancer RNAs; GFP: Green fluorescent protein; INDEL: Insertion or deletion; iPS: induced pluripotent stem (cells); qRT-PCR: real-time quantitative RT-PCR; TAD: Topologically associating domain; UTR: Untranslated region

\section{Acknowledgments}

We thank Daniela Moralli, Dianne Newbury and Sonja C. Vernes for comments to a first version of this manuscript.

\section{Funding}

This project was supported by funds from The University of Oxford (John Fell OUP Research Grant [121/435] awarded to Paloma García-Bellido), the Spanish National Research and Development Plan, Instituto de Salud Carlos III, and FEDER (FIS project no. PI14/01884 to Sandra Rodriguez-Perales), and the Spanish Ministry of Economy and Competitiveness (grant number FFI2016-78034-C2-2-P [AEI/FEDER,UE]) to Antonio Benítez-Burraco). The funders had no role in the study design, data collection and analysis, decision to publish, or preparation of the manuscript.

\section{Availability of data and materials}

All data generated or analysed during this study are included in this published article [and its Additional files].

\section{Authors' contributions}

PG-B conceived the project, participated in the design and coordination of experiments, analysed results, and wrote the paper. AB-B analysed results and wrote the paper. RT-R did the experiments, analysed results, and wrote the paper. MM-L did the experiments. SR-P participated in the design, coordinated experiments, analysed results, and wrote the paper. All authors read and approved the final manuscript.

\section{Ethics approval and consent to participate}

Ethics approval for this research was granted by the University of Oxford [MSD-IDREC-C1-2012-95, SSD/CUREC2/09-23].

\section{Consent for publication}

Not applicable.

\section{Competing interests}

The authors declare that they have no conflict of interest. 


\section{Publisher's Note}

Springer Nature remains neutral with regard to jurisdictional claims in published maps and institutional affiliations.

\section{Author details}

${ }^{1}$ Molecular Cytogenetics Group, Centro Nacional Investigaciones Oncológicas (CNIO), Madrid, Spain. ${ }^{2}$ Department of Spanish, Linguistics, and Theory of Literature (Linguistics), University of Seville, Seville, Spain. ${ }^{3}$ Faculty of Modern Languages, University of Oxford, Oxford, UK. ${ }^{4}$ Faculty of Linguistics, Philology and Phonetics, University of Oxford, Oxford, UK.

\section{Received: 9 February 2019 Accepted: 17 April 2019}

Published online: 02 May 2019

\section{References}

1. Vargha-Khadem F, Gadian DG, Copp A, Mishkin M. FOXP2 and the neuroanatomy of speech and language. Nat Rev Neurosci. 2005;6:131-8. https://doi.org/10.1038/nrn1605.

2. Vargha-Khadem F, Watkins K, Alcock K, Fletcher P, Passingham R. Praxic and nonverbal cognitive deficits in a large family with a genetically transmitted speech and language disorder. Proc Natl Acad Sci U S A. 1995;92:930-3.

3. Watkins KE, Dronkers NF, Vargha-Khadem F. Behavioural analysis of an inherited speech and language disorder: comparison with acquired aphasia. Brain. 2002;125:452-64. https://doi.org/10.1093/brain/awf058.

4. Shriberg LD, Ballard KJ, Tomblin JB, Duffy JR, Odell KH, Williams CA. Speech, prosody, and voice characteristics of a mother and daughter with a 7;13 translocation affecting FOXP2. J Speech Lang Hear Res. 2006;49:500-25. https://doi.org/10.1044/1092-4388(2006/038).

5. Zhao Y, Ma H, Wang Y, Gao H, Xi C, Hua T, Zhao Y, Qiu G. Association between FOXP2 gene and speech sound disorder in Chinese population. Psychiatry Clin Neurosci. 2010;64:565-73. https://doi.org/10.1111/j.1440-1819. 2010.02123.x.

6. Reuter MS, Riess A, Moog U, Briggs TA, Chandler KE, Rauch A, Stampfer M, Steindl K, Gläser D, Joset P, Study DDD, Krumbiegel M, Rabe H, SchulteMattler U, Bauer P, Beck-Wödl S, Kohlhase J, Reis A, Zweier C. FOXP2 variants in 14 individuals with developmental speech and language disorders broaden the mutational and clinical spectrum. J Med Genet. 2016.

7. Tolosa A, Sanjuán J, Dagnall AM, Moltó MD, Herrero N, de Frutos R. FOXP2 gene and language impairment in schizophrenia: association and epigenetic studies. BMC Med Genet. 2010;11:114.

8. Padovani A, Cosseddu M, Premi E, Archetti S, Papetti A, Agosti C, Bigni B, Cerini C, Paghera B, Bellelli G, Borroni B. The speech and language FOXP2 gene modulates the phenotype of frontotemporal lobar degeneration. J Alzheimers Dis. 2010;22:923-31. https://doi.org/10.3233/JAD-2010-101206.

9. Fisher SE, Scharff C. FOXP2 as a molecular window into speech and language. Trends Genet. 2009;25:166-77. https://doi.org/10.1016/j.tig.2009. 03.002.

10. Becker M, Guadalupe T, Franke B, Hibar DP, Renteria ME, Stein JL, Thompson PM, Francks C, Vernes SC, Fisher SE. Early developmental gene enhancers affect subcortical volumes in the adult human brain. Hum Brain Mapp. 2016;37:1788-800. https://doi.org/10.1002/hbm.23136.

11. Tsui D, Vessey JP, Tomita H, Kaplan DR, Miller FD. FoxP2 regulates neurogenesis during embryonic cortical development. J Neurosci. 2013;33: 244-58. https://doi.org/10.1523/JNEUROSCI.1665-12.2013.

12. Chiu Y-C, Li M-Y, Liu Y-H, Ding J-Y, Yu J-Y, Wang T-W. Foxp2 regulates neuronal differentiation and neuronal subtype specification. Dev Neurobiol. 2014;74:723-38. https://doi.org/10.1002/dneu.22166.

13. Garcia-Calero E, Botella-Lopez A, Bahamonde O, Perez-Balaguer A, Martinez S. FoxP2 protein levels regulate cell morphology changes and migration patterns in the vertebrate developing telencephalon. Brain Struct Funct. 2016;221:2905-17. https://doi.org/10.1007/s00429-015-1079-7.

14. Kurt S, Fisher SE, Ehret G. Foxp2 mutations impair auditory-motor association learning. PLoS One. 2012;7:e33130. https://doi.org/10.1371/ journal.pone.0033130.

15. Mueller KL, Murray JC, Michaelson JJ, Christiansen MH, Reilly S, Tomblin JB. Common genetic variants in FOXP2 are not associated with individual differences in language development. PLoS One. 2016;11:e0152576. https:// doi.org/10.1371/journal.pone.0152576.

16. Hoogman M, Guadalupe T, Zwiers MP, Klarenbeek P, Francks C, Fisher SE. Assessing the effects of common variation in the FOXP2 gene on human brain structure. Front Hum Neurosci. 2014;8:473.
17. Chandrasegaran S, Carroll D. Origins of programmable nucleases for genome engineering. J Mol Biol. 2016;428:963-89. https://doi.org/10.1016/j. jmb.2015.10.014

18. Schroeder DI, Myers RM. Multiple transcription start sites for FOXP2 with varying cellular specificities. Gene. 2008;413:42-8. https://doi.org/10.1016/j. gene.2008.01.015.

19. Bruce HA, Margolis RL. FOXP2: novel exons, splice variants, and CAG repeat length stability. Hum Genet. 2002;111:136-44. https://doi.org/10.1007/ s00439-002-0768-5.

20. Hallikas O, Palin K, Sinjushina N, Rautiainen R, Partanen J, Ukkonen E, Taipale J. Genome-wide prediction of mammalian enhancers based on analysis of transcription-factor binding affinity. Cell. 2006;124:47-59. https://doi.org/10. 1016/j.cell.2005.10.042.

21. Bonkowsky JL, Wang X, Fujimoto E, Lee JE, Chien C-B, Dorsky RI. Domainspecific regulation of foxP2 CNS expression by lef1. BMC Dev Biol. 2008;8: 103. https://doi.org/10.1186/1471-213X-8-103.

22. Shi Z, Luo G, Fu L, Fang Z, Wang X, Li X. miR-9 and miR-140-5p target FoxP2 and are regulated as a function of the social context of singing behavior in zebra finches. J Neurosci. 2013;33:16510-21. https://doi.org/10. 1523/JNEUROSCI.0838-13.2013.

23. Moralli D, Nudel R, Chan MTM, Green CM, Volpi EV, Benítez-Burraco A, Newbury DF, García-Bellido P. Language impairment in a case of a complex chromosomal rearrangement with a breakpoint downstream of FOXP2. Mol Cytogenet. 2015;8:36.

24. Becker M, Devanna P, Fisher SE, Vernes SC. A chromosomal rearrangement in a child with severe speech and language disorder separates FOXP2 from a functional enhancer. Mol Cytogenet. 2015;8. https://doi.org/10.1186/ s13039-015-0173-0.

25. Sakuma T, Woltjen K. Nuclease-mediated genome editing: at the front-line of functional genomics technology. Develop Growth Differ. 2014;56:2-13. https://doi.org/10.1111/dgd.12111.

26. Torres-Ruiz R, Rodriguez-Perales S. CRISPR-Cas9 technology: applications and human disease modelling. Brief Funct Genomics. 2016:elw025.

27. Rodriguez-Perales S, Torres-Ruiz R, Suela J, Acquadro F, Martin MC, Yebra E, Ramirez JC, Alvarez S, Cigudosa JC. Truncated RUNX1 protein generated by a novel $\mathrm{t}(1 ; 21)(\mathrm{p} 32 ; \mathrm{q} 22)$ chromosomal translocation impairs the proliferation and differentiation of human hematopoietic progenitors. Oncogene. 2016; 35:125-34. https://doi.org/10.1038/onc.2015.70.

28. Cong L, Ran FA, Cox D, Lin S, Barretto R, Habib N, Hsu PD, Wu X, Jiang W, Marraffini LA, Zhang F. Multiplex genome engineering using CRISPR/Cas systems. Science. 2013;339:819-23. https://doi.org/10.1126/science.1231143.

29. Mali P, Aach J, Stranges PB, Esvelt KM, Moosburner M, Kosuri S, Yang L, Church GM. CAS9 transcriptional activators for target specificity screening and paired nickases for cooperative genome engineering. Nat Biotechnol. 2013;31:833-8. https://doi.org/10.1038/nbt.2675.

30. Torres-Ruiz R, Martinez-Lage M, Martin MC, García A, Bueno C, Castaño J, Ramirez JC, Menendez P, Cigudosa JC, Rodriguez-Perales S. Efficient recreation of $\mathrm{t}(11 ; 22)$ EWSR1-FLI1(+) in human stem cells using CRISPR/Cas9. Stem Cell Reports. 2017;8:1408-20. https://doi.org/10.1016/j.stemcr.2017.04. 014.

31. Torres R, Garcia A, Jimenez M, Rodriguez S, Ramirez JC. An integrationdefective lentivirus-based resource for site-specific targeting of an edited safe-harbour locus in the human genome. Gene Ther. 2014;21:343-52. https://doi.org/10.1038/gt.2014.1.

32. Brinkman EK, Chen T, Amendola M, van Steensel B: Easy quantitative assessment of genome editing by sequence trace decomposition. Nucleic Acids Res 2014, 42:e168-e168, DOI: https://doi.org/10.1093/nar/gku936.

33. Hendel A, Bak RO, Clark JT, Kennedy AB, Ryan DE, Roy S, Steinfeld I, Lunstad BD, Kaiser RJ, Wilkens AB, Bacchetta R, Tsalenko A, Dellinger D, Bruhn L, Porteus $\mathrm{MH}$. Chemically modified guide RNAs enhance CRISPR-Cas genome editing in human primary cells. Nat Biotechnol. 2015;33:985-9. https://doi. org/10.1038/nbt.3290.

34. Rodriguez-Perales S, Torres-Ruiz R, Suela J, Acquadro F, Martin MC, Yebra E, Ramirez JC, Alvarez S, Cigudosa JC. Truncated RUNX1 protein generated by a novel $\mathrm{t}(1 ; 21)(\mathrm{p} 32 ; \mathrm{q} 22)$ chromosomal translocation impairs the proliferation and differentiation of human hematopoietic progenitors. Oncogene. 2015; 35:125-34.

35. Wang $H$, Yang $H$, Shivalila CS, Dawlaty MM, Cheng AW, Zhang F, Jaenisch $R$. One-step generation of mice carrying mutations in multiple genes by CRISPR/Cas-mediated genome engineering. Cell. 2013;153:910-8. https://doi. org/10.1016/j.cell.2013.04.025. 
36. Yang $H$, Wang $H$, Shivalila CS, Cheng AW, Shi L, Jaenisch R. One-step generation of mice carrying reporter and conditional alleles by CRISPR/Casmediated genome engineering. Cell. 2013;154:1370-9. https://doi.org/10. 1016/j.cell.2013.08.022.

37. Canver MC, Bauer DE, Dass A, Yien YY, Chung J, Masuda T, Maeda T, Paw $\mathrm{BH}$, Orkin $\mathrm{SH}$. Characterization of genomic deletion efficiency mediated by clustered regularly interspaced palindromic repeats (CRISPR)/Cas9 nuclease system in mammalian cells. J Biol Chem. 2014;289:21312-24. https://doi.org/ 10.1074/jbc.M114.564625.

38. Dow LE, Fisher J, O'Rourke KP, Muley A, Kastenhuber ER, Livshits G, Tschaharganeh DF, Socci ND, Lowe SW. Inducible in vivo genome editing with CRISPR-Cas9. Nat Biotechnol. 2015;33:390-4. https://doi.org/10.1038/ nbt.3155.

39. Chepelev I, Wei G, Wangsa D, Tang Q, Zhao K. Characterization of genomewide enhancer-promoter interactions reveals co-expression of interacting genes and modes of higher order chromatin organization. Cell Res. 2012;22: 490-503. https://doi.org/10.1038/cr.2012.15.

40. Xiong Q, Zhang Z, Chang K-H, Qu H, Wang H, Qi H, Li Y, Ruan X, Yang Y, Yang Y, Li Y, Sandstrom R, Sabo PJ, Li Q, Stamatoyannopoulos G, Stamatoyannopoulos JA, Fang $X$. Comprehensive characterization of erythroid-specific enhancers in the genomic regions of human Krüppel-like factors. BMC Genomics. 2013;14:587. https://doi.org/10.1186/1471-2164-14587.

41. Tak YG, Hung Y, Yao L, Grimmer MR, Do A, Bhakta MS, O'Geen H, Segal DJ, Farnham PJ. Effects on the transcriptome upon deletion of a distal element cannot be predicted by the size of the H3K27Ac peak in human cells. Nucleic Acids Res. 2016:44:4123-33. https://doi.org/10.1093/nar/gkv1530.

42. Spiteri E, Konopka G, Coppola G, Bomar J, Oldham M, Ou J, Vernes SC, Fisher SE, Ren B, Geschwind DH. Identification of the transcriptional targets of FOXP2, a gene linked to speech and language, in developing human brain. Am J Hum Genet. 2007;81:1144-57. https://doi.org/10.1086/522237.

43. Vernes SC, Spiteri E, Nicod J, Groszer M, Taylor JM, Davies KE, Geschwind $\mathrm{DH}$, Fisher SE. High-throughput analysis of promoter occupancy reveals direct neural targets of FOXP2, a gene mutated in speech and language disorders. Am J Hum Genet. 2007;81:1232-50. https://doi.org/10.1086/ 522238.

44. Paquet D, Kwart D, Chen A, Sproul A, Jacob S, Teo S, Olsen KM, Gregg A, Noggle S, Tessier-Lavigne M. Efficient introduction of specific homozygous and heterozygous mutations using CRISPR/Cas9. Nature. 2016;533:125-9. https://doi.org/10.1038/nature17664.

45. Vogel C, Marcotte EM. Insights into the regulation of protein abundance from proteomic and transcriptomic analyses. Nat Rev Genet. 2012;13:22732. https://doi.org/10.1038/nrg3185.

46. Rye M, Sætrom P, Håndstad T, Drabløs F. Clustered ChIP-Seq-defined transcription factor binding sites and histone modifications map distinct classes of regulatory elements. BMC Biol. 2011;9:80.

47. Ong C-T, Corces VG. Enhancer function: new insights into the regulation of tissue-specific gene expression. Nat Rev Genet. 2011;12:283-93. https://doi. org/10.1038/nrg2957.

48. Tsujimura T, Hosoya T, Kawamura S. A single enhancer regulating the differential expression of duplicated red-sensitive opsin genes in zebrafish. PLoS Genet. 2010;6:e1001245. https://doi.org/10.1371/journal.pgen.1001245.

49. Collins PL, Henderson MA, Aune TM. Lineage-specific adjacent IFNG and IL26 genes share a common distal enhancer element. Genes Immun. 2012; 13:481-8. https://doi.org/10.1038/gene.2012.22.

50. Lupiáñez DG, Spielmann M, Mundlos S. Breaking TADs: how alterations of chromatin domains result in disease. Trends Genet. 2016;32:225-37. https:// doi.org/10.1016/j.tig.2016.01.003.

51. Freeman LA, Garrard WT. DNA supercoiling in chromatin structure and gene expression. Crit Rev Eukaryot Gene Expr. 1992;2:165-209.

52. Heinzel T, Lavinsky RM, Mullen TM, Söderstrom M, Laherty CD, Torchia J, Yang WM, Brard G, Ngo SD, Davie JR, Seto E, Eisenman RN, Rose DW, Glass CK, Rosenfeld MG. A complex containing N-CoR, mSin3 and histone deacetylase mediates transcriptional repression. Nature. 1997;387:43-8. https://doi.org/10.1038/387043a0.

53. Frankel N, Davis GK, Vargas D, Wang S, Payre F, Stern DL. Phenotypic robustness conferred by apparently redundant transcriptional enhancers. Nature. 2010;466:490-3. https://doi.org/10.1038/nature09158.

54. Levine M. Transcriptional enhancers in animal development and evolution. Curr Biol. 2010;20:R754-63. https://doi.org/10.1016/j.cub.2010.06.070.
55. Perry MW, Boettiger AN, Levine M. Multiple enhancers ensure precision of gap gene-expression patterns in the Drosophila embryo. Proc Natl Acad Sci U S A. 2011;108:13570-5.

56. Spitz F, Furlong EEM. Transcription factors: from enhancer binding to developmental control. Nat Rev Genet. 2012;13:613-26. https://doi.org/10. 1038/nrg3207.

57. Davidson EH. Emerging properties of animal gene regulatory networks. Nature. 2010;468:911-20. https://doi.org/10.1038/nature09645.

58. Graham SA, Fisher SE. Decoding the genetics of speech and language. Curr Opin Neurobiol. 2013;23:43-51. https://doi.org/10.1016/j.conb.2012.11.006.

59. Thébault S, Gachon F, Lemasson I, Devaux C, Mesnard JM. Molecular cloning of a novel human I-mfa domain-containing protein that differently regulates human T-cell leukemia virus type I and HIV-1 expression. J Biol Chem. 2000;275:4848-57. https://doi.org/10.1074/jbc.275.7.4848.

60. Gautier W, Sheehy N, Duffy M, Hashimoto K, Hall WW. Direct interaction of the human I-mfa domain-containing protein, HIC, with HIV-1 tat results in cytoplasmic sequestration and control of tat activity. Proc Natl Acad Sci U S A. 2005;102:16362-7.

61. Kusano S, Yoshimitsu M, Hachiman M, Ikeda M. I-mfa domain proteins specifically interact with HTLV-1 tax and repress its transactivating functions. Virology. 2015;486:219-27. https://doi.org/10.1016/j.virol.2015.09.020.

62. Liégeois FJ, Hildebrand MS, Bonthrone A, Turner SJ, Scheffer IE, Bahlo M, Connelly A, Morgan AT. Early neuroimaging markers of FOXP2 intragenic deletion. Sci Rep. 2016;6:35192. https://doi.org/10.1038/srep35192.

63. Vernes SC. What bats have to say about speech and language. Psychon Bull Rev. 2016:1-7.

64. Chen B, Gilbert LA, Cimini BA, Schnitzbauer J, Zhang W, Li G-W, Park J, Blackburn EH, Weissman JS, Qi LS, Huang B. Dynamic imaging of genomic loci in living human cells by an optimized CRISPR/Cas system. Cell. 2013; 155:1479-91. https://doi.org/10.1016/j.cell.2013.12.001.

65. Clovis YM, Enard W, Marinaro F, Huttner WB, De Pietri Tonelli D. Convergent repression of Foxp2 3'UTR by miR-9 and miR-132 in embryonic mouse neocortex: implications for radial migration of neurons. Development. 2012; 139:3332-42. https://doi.org/10.1242/dev.078063.

\section{Ready to submit your research? Choose BMC and benefit from:}

- fast, convenient online submission

- thorough peer review by experienced researchers in your field

- rapid publication on acceptance

- support for research data, including large and complex data types

- gold Open Access which fosters wider collaboration and increased citations

- maximum visibility for your research: over $100 \mathrm{M}$ website views per year

At BMC, research is always in progress.

Learn more biomedcentral.com/submissions 